Jaromir Hovorka MD, Kari Korttila MD PhD, Olli Erkola MD

\title{
Nitrous oxide does not increase nausea and vomiting following gynaecological laparoscopy
}

The effect of three different anaesthetic techniques on the incidence and severity of postoperative emesis (nausea, retching and vomiting) was studied in 150 patients undergoing gynaecological laparoscopy. Patients were anaesthetized with isoflurane in nitrous oxide and oxygen (Group A), enflurane in nitrous oxide and oxygen (Group B) or with isoflurane in air and oxygen (Group C). Groups had been predetermined by date of birth. During the first 24 hours after the operation no difference was found at any time in the incidence or severity of emesis among the groups. The overall incidence of emesis during the first 24 hours postoperatively was 54,48 and 52 per cent, in groups $A, B$ and $C$, respectively. It is concluded that nitrous oxide does not increase the incidence of emesis after isoflurane anaesthesia and that isoflurane and enflurane anaesthesia are associated with similar incidences of nausea and vomiting after gynaecological laparoscopy.

We have conducted a series of studies in an attempt to decrease the incidence of postoperative nausea and vomiting but without complete success. ${ }^{1-3}$ It has been suggested that the administration of nitrous oxide is associated with a high incidence of nausea and vomiting. ${ }^{4}$ In our previous study, ${ }^{5}$ we did not find any decrease in postoperative emesis when nitrous oxide was omitted in patients undergoing gynaecological laparotomy under isoflurane anaesthesia. Because the literature ${ }^{6-7}$ regard-

\section{Key words}

ANAESTHETICS, GASES: nitrous oXide; ANAESTHETICS, VOLATILE: enflurane, isoflurane; COMPLICATIONS: nausea and vomiting; vomITING: nausea.

From the Department of Anaesthesia, Women's Clinics, Helsinki University Central Hospital, Haarmmaninkatu 2, SF00290 Helsinki, Finland.

Address correspondence to: Dr. J. Hovorka, Department of Anaesthesia, Women's Clinics, Helsinki University Central Hospital, Haartmaninkatu 2, SF-00290 Helsinki, Finland. ing nausea and vomiting and administration of nitrous oxide for patients undergoing gynaecological surgery is controversial, we conducted a similar study to determine to what extent nitrous oxide contributes to the occurrence of postoperative emesis during the first 24 hours after isoflurane anaesthesia.

\section{Methods}

One hundred and fifty patients scheduled for elective gynaecological inpatient laparoscopy were entered into the study. The study protocol was accepted by the institutional ethics committee and informed consent for the study was obtained from each patient. Only patients in ASA physical status I or II were studied. The type of anaesthesia had been predetermined by the date of birth (day) to receive one of the three techniques. The person evaluating emesis was not aware of the method of anaesthesia used.

The patients were premedicated with oxycodone chloride $0.13 \mathrm{mg} \cdot \mathrm{kg}^{-1} \mathrm{IM} 40-60 \mathrm{~min}$ before anaesthesia. After the insertion of an IV cannula and the start of an IV infusion (lactated Ringer's solution), $0.8 \mathrm{mg}$ of vecuronium, $0.2 \mathrm{mg}$ of glycopyrrolate and $0.1 \mathrm{mg}$ of fentanyl were administered. Two minutes later anaesthesia was induced with $4 \mathrm{mg} \cdot \mathrm{kg}^{-1}$ of thiopentone. Oral intubation was facilitated with $1.5 \mathrm{mg} \cdot \mathrm{kg}^{-1}$ of succinylcholine and anaesthesia was maintained with isoflurane in nitrous oxide and oxygen ( 30 per cent), enflurane with nitrous oxide and oxygen ( 30 per cent) or isoflurane in air and oxygen (30 per cent) administered in semi-open or semi-closed system. The initial inspired concentration of isoflurane was one per cent for those given nitrous oxide and 1.5 per cent for those not given nitrous oxide. The initial inspired concentration of enflurane was 1.2 per cent. Thereafter gases were administered according to clinical needs, the concentration being changed if, during surgery, the systolic blood pressure or heart rate changed more than 25 per cent from baseline. Inspired and end-tidal concentrations of isoflurane and enflurane were measured with an anaesthetic agent monitor and average 
isoflurane and enflurane concentrations were estimated from the anaesthesia chart.

Vecuronium was used to maintain 20 per cent to 25 per cent of twitch response to nerve stimulation. End-tidal $\mathrm{CO}_{2}$ was measured continuously with a capnometer in order to maintain end-tidal $\mathrm{CO}_{2}$ at $5.0-5.5$ per cent.

At the end of anaesthesia, glycopyrrolate $0.4 \mathrm{mg}$ and neostigmine $2.0 \mathrm{mg}$ were given IV. Oxycodone chloride, to relieve postoperative pain, was administered intravenously in the recovery room in $4 \mathrm{mg}$ increments and thereafter intramuscularly in the ward, at a dose of 0.13 $\mathrm{mg} \cdot \mathrm{kg}^{-1}$. Droperidol, $1.25 \mathrm{mg}$, was used to treat prolonged postoperative nausea or vomiting.

\section{Assessment of emesis}

The incidence of nausea and vomiting was determined at different intervals during the first 24 hours after the operation; from 0 to 2,2 to 6,6 to 12,12 to 18 and 18 to 24 hours, as in our previous studies. ${ }^{1-3,5}$ At the end of each interval, a trained nurse, unaware of the anaesthetic administered, registered whether nausea, retching or vomiting had occurred. The results were scored in a manner similar to that of Bellville et al.:.$^{8}$ none, nausea, retching, vomiting. Droperidol $1.25 \mathrm{mg}$ was administered once during each period for prolonged nausea or vomiting. If a patient experienced nausea, retching and vomiting, i.e., all emetic side effects, she was listed in the most severe category. For example, if a subject experienced both nausea and vomiting, she was listed as having vomited; each patient was assessed five times during the 24-hour period.

\section{Statistics}

Analysis of variance was used for comparisons of the patients' characteristics and of the types of anaesthesia. The chi-square test was used to compare the incidence of emesis. A P value less than 0.05 was considered statistically significant.

\section{Results}

There were 50 patients in each group. The characteristics of the patients and of the anaesthesia are shown in Table $I$. The three groups were comparable with regard to age, weight and duration of anaesthesia. The history of nausea and vomiting after previous anaesthetics was evenly distributed in each group. The doses of vecuronium required for muscle relaxation and of fentanyl given perioperatively and oxycodone given postoperatively were also similar in all groups. Approximately half of the patients in all groups were given droperidol as an anti-emetic drug.

Table II shows that the incidence and severity of emesis at any time during the 24-hour follow-up period were
TABLE I Characteristics of the test groups (mean \pm SD)

\begin{tabular}{|c|c|c|c|}
\hline & \multicolumn{3}{|l|}{ Ancesthesia } \\
\hline & $\begin{array}{l}\text { Isoflurane } \\
\text { in } \mathrm{N}_{2} \mathrm{O}-\mathrm{O}_{2}\end{array}$ & $\begin{array}{l}\text { Enflurane } \\
\text { in } \mathrm{N}_{2} \mathrm{O}-\mathrm{O}_{2}\end{array}$ & $\begin{array}{l}\text { Isoflurane } \\
\text { in air- } \mathrm{O}_{2}\end{array}$ \\
\hline $\mathrm{N}$ & 50 & 50 & 50 \\
\hline Age (ys) & $32.6 \pm 7$ & $32.7 \pm 6$ & $32.8 \pm 7$ \\
\hline Weight (kg) & $6] .3 \pm 8$ & $60.5 \pm 10$ & $59.7 \pm 7$ \\
\hline $\begin{array}{l}\text { Duration of anaesthesia } \\
\text { (min) }\end{array}$ & $37.8 \pm 13$ & $40.2 \pm 10$ & $37.5 \pm 10$ \\
\hline $\begin{array}{l}\text { Average inspired } \\
\text { concentration of } \\
\text { inhalation agent }(\%)\end{array}$ & $1.1 \pm 0.18$ & $1.2 \pm 0.21$ & $1.59 \pm 0.22$ \\
\hline Vecuronium (mg) & $4.8=1.2$ & $4.0 \pm 0.9$ & $4.8 \pm 1.0$ \\
\hline $\begin{array}{l}\text { Oxycodone for postop. } \\
\text { pain (total mg) }\end{array}$ & $10.4 \pm 9.6$ & $11.9 \pm 8.6$ & $13.9 \pm 10.1$ \\
\hline $\begin{array}{l}\text { Droperidol for postop. } \\
\text { emesis (total mg) }\end{array}$ & $0.72 \pm 1.0$ & $0.45 \pm 0.8$ & $0.85 \pm 1.3$ \\
\hline
\end{tabular}

similar in all groups. Similarly, the incidence of the nausea, retching and vomiting did not differ among the groups when assessed for the whole 24-hour follow-up period. The overall incidence of emesis (either nausea, retching or vomiting) during 24 hours was 54,48 and 52 per cent in isoflurane- $\mathrm{N}_{2} \mathrm{O}-\mathrm{O}_{2}$, enflurane- $\mathrm{N}_{2} \mathrm{O}-\mathrm{O}_{2}$ and isoflurane-air- $\mathrm{O}_{2}$ groups, respectively. Emesis was not severe during the 2-12 hours after anaesthesia and had nearly disappeared by 24 hours. There were no statistically significant differences among the study groups during any of the studied intervals.

There were no complaints of awareness during anaesthesia in any group, and all three techniques provided satisfactory anaesthesia with good surgical conditions and patient acceptance.

\section{Discussion}

In the present investigation, administration of all three anaesthetic techniques was associated with a similar incidence of emesis after laparoscopy. Omission of nitrous oxide from anaesthesia did not alleviate postoperative emesis.

The trial design and scoring system used for nausea and vomiting in this study have been used by our group before and have proved useful and sensitive in evaluating the postoperative anti-emetic efficacy of drugs after general anaesthesia. ${ }^{1-3.5} \mathrm{~A}$ comparison of the emetic symptoms is justified in the present jnvestigation, since the variables which most affect the incidence of nausea and vomiting ${ }^{9}$ (i.e., age, sex, type and duration of operation, amounts of narcotic given) were very similar in all three groups. Although the administration of narcotic analgesics may cause nausea and vomiting, we chose to use oxycodone for premedication and a small dose of fentanyl before the induction of anaesthesia, as pain after operation has also 
TABLE II Percentage incidence of emesis (nausea, retching or vomiting) after three different anaesthetics in women undergoing laparoscopy under general anaesthesia

\begin{tabular}{|c|c|c|c|}
\hline \multirow[b]{2}{*}{ Assessment } & \multicolumn{3}{|l|}{ Anaesthesia } \\
\hline & $\begin{array}{l}\text { Isoflurane in } \\
\mathrm{N}_{2} \mathrm{O}-\mathrm{O}_{2}\end{array}$ & $\begin{array}{l}\text { Enflurane in } \\
\mathrm{N}_{2} \mathrm{O}-\mathrm{O}_{2}\end{array}$ & $\begin{array}{l}\text { Isoflurane in } \\
\text { air- } \mathrm{O}_{2}\end{array}$ \\
\hline \multicolumn{4}{|l|}{ Emesis (overall) } \\
\hline \multicolumn{4}{|l|}{$0-24$ hrs after } \\
\hline anaesthesia & 54 & 48 & 52 \\
\hline \multicolumn{4}{|l|}{ Emesis $0-2$ hrs } \\
\hline after anaesthesia & 26 & 16 & 16 \\
\hline None & 74 & 84 & 84 \\
\hline Nausea & 14 & 10 & 8 \\
\hline Retching & 8 & 4 & 8 \\
\hline Vomiting & 4 & 2 & 0 \\
\hline \multicolumn{4}{|l|}{ Emesis 2-6 hrs } \\
\hline after anaesthcsia & 34 & 30 & 32 \\
\hline None & 66 & 70 & 68 \\
\hline Nausea & 20 & 14 & 14 \\
\hline Retching & 4 & 6 & 12 \\
\hline Vomiting & 10 & 10 & 6 \\
\hline \multicolumn{4}{|l|}{ Emesis $6-12 \mathrm{hrs}$} \\
\hline after anaesthesia & 18 & 32 & 32 \\
\hline None & 82 & 68 & 68 \\
\hline Nausea & 4 & 16 & 16 \\
\hline Relching & 8 & 4 & 6 \\
\hline Vomiting & 6 & 12 & 10 \\
\hline \multicolumn{4}{|l|}{ Emesis $12-18$ hrs } \\
\hline after anjesthesia & 2 & 12 & 6 \\
\hline None & 98 & 88 & 94 \\
\hline Nausca & 0 & 6 & 2 \\
\hline Retching & 2 & 4 & 0 \\
\hline Vomiting & 0 & 2 & 4 \\
\hline \multicolumn{4}{|l|}{ Emesis $18-24$ hrs } \\
\hline after anaesthesia & 2 & 2 & 2 \\
\hline None & 98 & 98 & 98 \\
\hline Nausea & 2 & 2 & 0 \\
\hline Retching & 0 & 0 & 2 \\
\hline Vomiting & 0 & 0 & 0 \\
\hline
\end{tabular}

been implicated as a major cause of postoperative nausea. ${ }^{10}$ The overall incidence of emesis in this study (54 per cent for isoflurane- $\mathrm{N}_{2} \mathrm{O}-\mathrm{O}_{2}, 48$ per cent for enflurane $\mathrm{N}_{2} \mathrm{O}-\mathrm{O}_{2}$ and 52 per cent for isoflurane-air- $\mathrm{O}_{2}$ ) is rather high for relatively short anaesthesia. It can be explained by meticulous follow-up of all patients, when even short-lasting, minor nausea had been registered. Our sample size may have been too small to reveal small effects of nitrous oxide. However, power analysis ${ }^{11}$ indicated that we had an 80 per cent chance of finding an effect of nitrous oxide had the incidence of emesis increased by 40 per cent (i.e., from 50 per cent to 70 per cent).

Using similar anaesthetic techniques, Lonie and Harper, ${ }^{6}$ studied postoperative nausea and vomiting after enflurane anaesthesia with or without nitrous oxide. They reported that patients who did not receive nitrous oxide vomited less frequently than those who received nitrous oxide. Our present study reports agree with those of Melnick and Johnson ${ }^{7}$ and indicate that nitrous oxide does not increase nausea and vomiting.

In our previous study, ${ }^{5}$ we investigated nausea and vomiting after isoflurane anaesthesia with or without nitrous oxide for gynaecological laparotomy. In that investigation, nitrous oxide did not increase the incidence or severity of emesis after operation. Muir et al. ${ }^{9}$ found no association between the use of nitrous oxide and postoperative nausea and vomiting in patients undergoing a variety of surgical procedures under enflurane or isoflurane anaesthesia with or without nitrous oxide

Nitrous oxide is used routinely in most general anaesthetics administered today. The possible mechanisms by which nitrous oxide could be implicated in the incidence of emesis is increased sympathetic stimulation, increase in middle ear pressure and possible distention of the intestines.

As the omission of nitrous oxide from the anaesthetic technique used in this study did not decrease the incidence of postoperative nausea or vomiting, the use of nitrous oxide need not be avoided in women undergoing gynaecological laparoscopy. After laparoscopy, nausea and vomiting are as common after isoflurane as after enflurane anaesthesia.

\section{References}

1 Kortila $K$, Kauste A, Auvinen J. Comparison on domperidone, droperidol, and metoclopramide in the prevention and treatment of nausea and vomiting after balanced general anaesthesia. Anest Analg 1979; 58: $396-400$.

2 Kortila $K$, Kauste A, Tuominen $M$, Salo $H$. Droperidol prevents and treats nausea and vomiting after enflurane anaesthesia. Eur J Anaesth 1986; 2: 379-85.

3 Kausie A, Tuominen M, Heikkinen $H$, Gordin A, Kortrila $K$. Droperidol, alitsapride and metoclopramide in the prevention and treatment of postoperative emetic scquelac. Eur J Anaesth 1986; 3: 1-9.

4 Alexander $G D$, Skupski JN, Brown EM. The role of nitrous oxide in postoperative nausea and yomiting. Anesth Analg 1984; 63: 175.

5 Kartila $K$, Hovorka J, Erkola $O$. Nitrous oxide does not increase the incidence of nausea and vomiting after isoflurane anesthesia. Anesth Analg 1987; 66: 761-5. 
6 Lonie DS, Harper NJN. Nitrous oxide anaesthesia and vomiting. Anaesthesia 1986; 41: 703-7.

7 Melnik BM. Johnson LS. Effect of eliminating nitrous oxide in outpatient anesthesia. Anesthesiology 1987; 67: $982-4$.

8 Bellville JW, Bross IDJ, Hawland WS. A method for the clinical evaluation of antiemetic agents. Anesthesiology 1959; 20: 753-60.

9 Muir JJ, Warner MA, Offort KP, Buck CV. Harper JV, Kunkel SE. Role of nitrous oxide and other factors in postoperative nausea and vomiting: a randomized and blinded prospective study. Anesthesiology 1987; 66: 5!3-8.

10 Anderson $R, K \operatorname{rogh} K$. Pain as a major cause of postoperative nausea. Can Anaesth Soc J 1976; 23: 366-9.

11 Fleiss $J L$. Statistical methods for rates and proportions. 2nd Edition New York. John Wiley and Sons. 1981, pp. 258-80.

\section{Résumé}

L'effet de trois différentes techniques anesthésiques sur l'incidence et la sévérité du vomissement postopératoire (nausées, haul-le-cour et vomissements) a été étudié chez 150 patientes devant subir une laparoscopie pour opérations gynécologiques. Les patientes furent anesthésiées avec isoflurane, protoxyde d' azote et oxygène (Groupe A), enflurane, protoxyde d'azote et oxygène (Groupe B) ou avec isoflurane, air et oxygène (Groupe C). Les groupes ont été prédéterminés par la date de naissance. Durant les premières 24 heures postop aucune différence ne fut mentionnée en aucun temps sur l'incidence ou la sévérité des vomissements entre les groupes. $L$ 'incidence totale des vomissements durant les premières 24 heures postopératoires était de 54,48 et 52 pour cent duns les groupes $A, B$ et $C$ respectivement. On conclut que le protoxyde d'azote n'augmente pas l'incidence des vomissements après l'anesthésie à l'isoflurane et que l'anesthésie à l'isoflurane et l'enflurane est associée avec une incidence identique de nausées et vomissements après taparoscopie pour opération gynécologique. 